\title{
Sexual Education Knowledge for Early Childhood
}

\author{
Weny Savitry S. Pandia, Yapina Widyawati, Etty Indriati
}

Fakultas Psikologi UnikaAtma Jaya, Jakarta, Indonesia

Corresponding e-mail: weny.sembiring@atmajaya.ac.id

\begin{abstract}
Nowadays, the case of child sexual abuse (CSA) is increasing. Parents need to prevent the occurrence of sexual assaults. This can be started by educating their child about sex through daily communication, for example, by teaching children about their personal body areas and how to protect them. Books can be a good source for parents and children to improve their knowledge. This study assessed the differences between parents' knowledge on CSA prevention before and after reading a book of such nature. This research also investigated children's knowledge of CSA after being read by parents and teachers for 1 month (30 days) with 10 minutes per day of reading time. Mixed methods were used in this study to answer the research questions. Pre-test and post-test questionnaire and monitoring forms were given to 64 parents. They are from two Early Childhood Education, religious based program (Pendidikan Anak Usia Dini - PAUD). Three parents and two teachers were interviewed and 30 students from TK B (60-72 months old) were observed. The result showed that there was no knowledge differences of parents before and after reading the book to children $(r=0.70$; Sign $=0.535)$. This, presumably, because parents have previous basic knowledge of sexual abuse prevention in regard to which part of the body should be covered or not, can be touched or not, who may touch the body and for what purpose, and what to do in case sexual assault occurred. From the interviews, the parents realized the book was an important learning media and did provide them with new knowledge regarding the prevention of sexual assault. Based on observation of the children and the interview with the teachers, the book gave important knowledge to children on how to prevent CSA.
\end{abstract}

Keywords: Early childhood, child sexual abuse, sexual education

\section{INTRODUCTION}

The prevalence of child sexual abuse (CSA) in Indonesia is increasing. CSA is defined as the imposition of adults who demonstrate or perform sexual behaviour on children with threat to conceal. It is also accompanied by violence which can cause frightened, feeling under domination, exploitation, and loss of control over their bodies (Indriati, 2014). Centre for Data and Information of the National Commission for Child Protection of Indonesia noted that in 2010-2014 there are 21,869,797 cases of violation of child rights in 34 provinces and 179 districts and cities. $42-58 \%$ of children's rights cases of violation are sexual crimes against children. Worst still, victims of sexual crimes against children has been to be increasing every year. In 2010 there were 2,046 cases of crime, $42 \%$ of them are cases of sexual offenses. In 2013, out of 3339 cases of violence, $62 \%$ of those cases were sexual violence.

Children in their early years, under the age of 6 , are vulnerable. One of the reasons is their immaturity of verbal skills. Those children do not have enough vocabulary to be able to explain what happened when CSA occurs. Other aspect such as culture also determines this situation. In Indonesian, mentioning the scientific name of the genitals is considered to be impolite or taboo. Sometimes people use other term to mention it. This would limit the vocabulary to describe what happened to them. They did not report it because they do not understand what happened and do not have the vocabulary for their genitals and the sexual behaviour in their system of cognitive (Indriati, 2014; Bebbington et.al, 2011). CSA has a long term emotional, sexual, or physical negative effect on child's life, including adult depression, personality 
disorder, PTSD, drug and alcohol abuse, bulimia and suicidality (Bebbington et.al, 2011; Scrandis \& Watt, 2014).

The environment is a very important factor to prevent the case of CSA. Parents, teachers, and the community should take a part to prevent CSA by providing knowledge to children, in order to make them understand CSA and know how to respond to it (Sieswerda \& Blekkenhorst, 2006; Indriati, 2014; Chen \& Chen, 2015; Okoroafor, 2012).

Research by Sieswerda and Blekkenhorst (2006) in Canada found that family have important role in sexual education and should be a comfortable place for children to discuss reproductive health issues. However, some parents need several times to be able to discuss sexuality with their children. Parents usually wait until the child become adolescent. The topics of sexual education are in the area of puberty problems such as menstruation and wet dreams. Parents find it difficult to deliver sexual knowledge to their children at home. In Dyson (2010), there is a need for resources to support parents and family members as sexuality educators of their children.

In Indonesia, research completed by Wiradjaja (2014) regarding the perceptions and knowledge of parents confirm that parents consider themselves first and school as the second most responsible person for providing sexual education to their children. Research by Visi (2014) about knowledge, attitudes, and actions of mothers on sexual education in adolescents explain that mothers' knowledge varied. Mother's attitudes towards sexual education tend to be negative, and the actions taken by mothers tend to be passive. Some factors influenced this result such as environmental factors, level of education, experience, religious beliefs, as well as social and cultural perspective.

At an early age, especially when the child has entered school years, children have other sources of information such as teachers and school friends. At this age children would frequently mention the words that seem taboo about sexuality. In fact they do not know exactly the meaning of these words. Children express the word in order to grasp the reaction of the people around, especially their parents. Early childhood is at risk period to CSA. This is the time they enter into the broader environment. Their parents need to understand this situation and equip their children with basic skill to prevent the occurrence of CSA (Indriati, 2014).

Walker and Derbyshire Healthy Schools (in Parents and SRE, 2011) mention that parents need references, such as books, that will help them in educating children related to sexuality and human relationships. Parents also need suggestions to solve various things that the child asked. Parent's knowledge is very important, because by having adequate knowledge parents can teach children about how to prevent CSA.

The effective method to prevent children from CSA is by teaching them how to protect their private body parts. This can be done if the parents have a good knowledge of sexual education (Federal Centre for Health Education, 2010; Parents \& SRE, 2011; Major, 2011). In Indriati (2014), the way to do this is by teaching them to cross their arms in their private body part such as mouth to protect them from forced oral sex, chest to protect them from sexual touching, genitals to protect them from sexual coercion and also their rectum. Indriati (2014) also mentioned that children's knowledge of sexuality make them understand about it and have some vocabulary to express the adult if he or she is treated or seen an adult sex crimes to another child. Though, without being given a basic knowledge of the private parts of the body from an early age, they will have this knowledge when they enter adolescence. In adolescence they know about sexuality, sexual abuse, and rape. The understanding about forbidden parts of the body that should not be touch inappropriately by the adults, shouting the word "cannot / do not", and tell an adult if anyone done CSA will help children to have self-defence and make the child has control over his body.

The objectives of this study were to understand the difference of parental knowledge about sexual education in early childhood after reading a book about sexuality to children. The research measured 1) the opinion of parents about the importance of giving sexual education for children; 2 ) to what extent was the parents' knowledge about private body part in children; 3 ) to what extent parents understand the child's private body parts; 4) to what extent parents understand who is the person that may touch the child's body and for what purpose; and 5) to what extent parents understand how to teach children about what to do if something goes wrong (Indriati, 2014). The present study also wanted to have a better understanding on the differences in children's knowledge before and after given sexual education through the book that was readto them. 


\section{METHOD}

The method of this research was a quasiexperimental with mixed method, with accidental sampling. The participants were 64 parents of two institutions of formal Early Childhood Education (ECD), 2 teachers and 30 students. Both institutions were religious based educational institutions. The procedure was as followed: Parents were given an explanation of the CSA and of the research purposes, and then the pre-test questionnaire was given to the parents. Parents were instructed to read the book "Badanku Milikku" (My body is mine) (Indriati, 2014) every night before bed for 10 minutes for the length of 1 month (30 days). At the end of the given time, parents were to fill out a monitoring table to control the consistency of story telling activity. Parents were also asked to record the children's reaction that occurs when the story is read, also any behavioural changes that occurs during the first month. After a period of 1 month parents were asked to fill out the post test. At schools, teachers were also asked to do the same procedure.

We also analyzed the monitoring table and conducted interview with two teachers and three parents.

\section{RESULT AND DISCUSSION}

\subsection{Quantitative analysis}

Comparative analyses conclude that there were no significant differences between those parents' knowledge prior and after the book reading. Data showed that there was no difference between pre-test and post-test score at Kindergarten A (Sign score $0.402)$. There was no difference between pre-test and post-test score at Kindergarten $\mathrm{B}(\mathrm{z}=-1.135$, Sign $=0.256$ ).

Table 1 Comparative analysis on pre-test and post-test at Kindergarten A and B

\begin{tabular}{|c|c|c|c|c|}
\hline & Mean & $\mathrm{N}$ & $\mathrm{SD}$ & Std. Error Mean \\
\hline Presc A & 51.69 & 11 & 4.988 & 0.624 \\
\hline Presc B & 50.59 & 53 & 7.805 & 0.976 \\
\hline \multicolumn{5}{|c|}{ Correlation } \\
\hline & \multicolumn{2}{|c|}{0.079} & & \\
\hline
\end{tabular}

There was no difference in all subject $(\mathrm{r}$ Sign $=$ 0,535 ). It means that there was not found any significant differences in the knowledge of parents before and after reading stories to children.

\subsection{Qualitative analysis}

Parents have a positive reaction to the book. It can be can be used to provide sexual education to children. They can use the book as a media or a tool to teach children on sexual education.

At the beginning, parents were worry that children would get bored and refused the book. Parents at kindergarten A confirmed of having of this feeling because that school is an inclusive school. However the children liked to have the book read to them. They would ask for more when the reading time was about to end. Parents were cooperative to the procedure. But sometimes, parents did not read a book because some reasons such as forgetting they have to read, leaving the book behind at grandma's house, or the child was sick.

From the observations of parents and teachers, children's knowledge was improved after 1 month. Children knew the proper names for body parts. They were no longer use inappropriate noun for body areas. They knew to keep their body part clean. They also knew what to do if there were abusive situations happen. However, the children became very sensitive to his/her body. They were easily to scream when friends touched their body part although it was not a private area. There was a child who screamed and reported to the teacher when a friend lifted her skirt up with the intention of joking. At home, all the children were read stories by their mother though in this study it was not restricted of who should read the story to the children.

\subsection{Discussion}

In Sieswerda and Blekkenhorst (2006), parents realize they were an important and the primary figure in teaching sexuality to children. They also need to be open minded on these issues. Result from this study were supportive of the previous study by Sieswerda and Blekkenhorst (2006), parents were enthusiastic and opened to having their children to be taught by other party on sexual education.

The Federal Centre for Health Education (2010) mentioned that parents need to educate children in sexual issues. Through this study, parents have become aware that sexual education should be 
provided intentionally. What is given to children are also aligned with the characteristics of sexuality education proposed by WHO (the Federal Centre for Health Education), which are interactive, continuity, awareness of local wisdom such as the language, involving parents and the community (teachers and children).

Sieswerda and Blekkenhorst (2006) states there was discrepancy between the father and mother. They had different opinions on the person who is the most suitable to educate children at home about sexual issues. In general, mothers thought that they were the ones who supposedlyhad to give the sexual education. The fathers considered that sex education should be given in cooperation by the father and mother. In this study, most of the mother read stories to children every day. Qualitative analysis found that mothers were more involved in sexual education. In general parenting, mother has a greater role in early development years. Father seems to be more involved at a later stage especially at the beginning of puberty in their son development. In his research, Walker (2001) stated that mothers perceived the sources of information written by men, would assist the mother in providing sexual education to the boys. Further research is needed to be able to discuss this matter since it is not the objective of this study.

Early sexual education needs to be given as early as possible, with content that are suitable for a child's age level. Berk (2013) explained that the children were able to process the information more efficiently than adults. This potential is actualized through every day reading activity at home or at school. They easily recall the information because they process it immediately. This explained why the sexual education program given in this study was able to improve children's knowledge of CSA prevention.

Previous studies show that socio-economic, educational and cultural backgrounds could affect the mother's knowledge about sexual education (Visi, 2014) therefore further research should control this. It is also necessary to consider parental education level, socio-economic background and culture, and previous experience in further research. This research recommends that parents'attitudes and actions on the prevention of sexual abuse to be investigated in further research in every stage of child development such as at early childhood, or middle or late stage of child development. In this study, we gathered data from two religious based schools. It is assumed that, parents from this school gave their children value or morals about social life from the beginning of child development. It could be done through their religious life.

It is also important to monitor the improvement of children's knowledge before and after the reading procedure. This study assumed that parents have a basic knowledge of teaching CSA prevention to their children, but parents still need to be cautious and keep improving their knowledge of the prevention of CSA. Early sexual education should be given as early as possible with age-approriate approach.

\section{CONCLUSIONS}

This study provided evidence about knowledge of the parents. There was not found any significant differences in the knowledge of parents before and after reading stories to children. However, the knowledge of children was improved after being read by their parents and teachers. Parents had basic knowledge about sexuality but they had difficulty on educating their children. The book "Tubuhku milikku" (My body is mine) facilitated parents to introduce and educate children about sexuality.

\section{REFERENCES}

Bebbington, P. E., Jonas S., Brugha, T, Meltzer, H., Jenkins, R., Cooper, C., King, M., \& McManus, S. (2011). Child sexual abuse reported by an English national sample: Characteristics and demography. Social Psychiatry Epidemiology, 46, 255-262.

Berk, L. E. (2013). Child development $\left(9^{\text {th }} e d\right)$. Singapore: Pearson

Chen, J. Q. \& Chen, D. G. (2015). Awareness of child sexual abuse prevention education among parents of Grade 3 elementary school pupils in Fuxin, China. Health Education Research, vol. 20 no. 5, 540-547. DOI: 10.1093/her/cyh012.

Dyson, S. (2010). Parents and sex education: Parent's attitudes to sexual health education in WA School. Melbourne: La Trobe University

Federal Centre for Health Education. (2010). Standards for sexuality education in Europe: A framework for policy makers, educational and health authorities and specialists. Europe: WHO

Major, W. M. (2011). Child sexual abuse: a New approach to professional education. Nursing Standard, 25, 37, 35-40.

Okoroafor, N., C. (2012). Primary prevention knowledge of parents and teachers of nursery 
and play group on childhood sexual abuse. International Journal of Evaluation and Research in Education, vol. 1 no. 2, 73-78.

Parents and SRE: A sex education forum evidence briefing. (2011). Downloaded from www.sexeducationforum.org.uk. at November 10th 2014.

Indriati, E. (2014). Anakku sayang! Anakku aman! Menghindarkan anak dari kejahatan seksual. Jakarta: PT Gramedia Pustaka Utama (2014). Badanku milikku:

Pengenalan bagian tubuh untuk mencegah kejahatan seksual pada anak. Jakarta: PT Gramedia Pustaka Utama.

Scrandis, D. A. \& Watt, M. (2014). Child sexual abuse in Boy: Implications for primary care. The Journal for Nurse Practitioners, 10, 9, 706713.

Sieswerda, L. E. \& Blekkenhorst, P. (2006).

Parental attitudes towards sex education in the home: Results of a 2003 parent survey conducted in Thunder Bay, Ontario. Canada: Thunder Bay District Health Unit

Visi, V. (2014). Gambaran pengetahuan, sikap, dan tindakan ibu terhadap pendidikan seksual pada remaja autism. Skripsi. Fakultas Psikologi UAJ.

Walker, J. W. (2001). A qualitative study of parents' experiences of providing sex education for their children: The implications for health education. Health Education Journal; 60; 132

Wiradjaja, N. (2014). Persepsi dan pengetahuan Orangtua murid SMP Notredame dan Santo Paulus Terhadap Pendidikan Seksualitas. Skripsi. Fakultas Kedokteran UAJ. 